\title{
Redaktionen har modtaget
}

BERTELSEN, ANNE METTE HOLME \& CAMILLA GOHR: Den gode fødsel. En antropologisk undersøgelse af fødselsfortællingen. København: Museum Tusculanums Forlag 2006. 192 sider. ISBN 87-635-0496 0. Pris: 198 kr.

JENKINS, RICHARD: Social identitet. Århus: Academica 2006. 240 sider. ISBN 87-7675103-1. Pris: $276 \mathrm{kr}$.

KARREBÆK, MARTHA SIF (red.): Tosprogede børn i det danske samfund. En grundbog. København: Hans Reitzels Forlag 2006. 239 sider. ISBN 87-412-0360-7. Pris: 239 kr.

LATOUR, BRUNO: Vi har aldrig været moderne. København: Hans Reitzels Forlag 2006. 251 sider. ISBN 87-412-0217-1. Pris: $298 \mathrm{kr}$.

MØRCK, LINE LERCHE: Grænsefællesskaber. Læring og overskridelse af marginalisering. Frederiksberg: Roskilde Universitetsforlag 2006. 286 sider. ISBN 87-7867-336-4. Pris: 298 kr.

OTTO, TON, HENTRIK THRANE \& HELLE VANDKILDE (eds.): Warfare and Society. Archaeological and Social Anthropological Perspectives. Århus: Aarhus University Press 2006. 557 sider, ill. ISBN 87-7934 110-1 (hb). Pris: £30.95, \$53, •45.95.

PÉCSELI, BENEDICTA (red.): Kultur og forståelse. Kulturvidenskab for de pædagogiske fag. København: Hans Reitzels Forlag 2006. 205 sider. ISBN 87-412-0231-7. Pris: 225 kr.

RIIS, OLE: Samfundsvidenskab i praksis. Introduktion til anvendt metode. København: Hans Reitzels Forlag 2005. 228 sider. ISBN 87-412-0363-1. Pris: 298 kr.

RUBOW, CECILIE: Fem præster - og antropologiske perspektiver på identitet og autoritet. København: Forlaget ANIS 2006. 238 sider. ISBN 87-7457-374-8. Pris: 249 kr.

SKOVHOLM, JENS (red.): Et spørgsmål om kultur? Rundt om mødet mellem den professionelle og etniske minoriteter. København: Dansk Flygtningehjælp 2005. 223 sider. ISBN 87-7710-438-2. 